\title{
Evaluasi Kondisi Terumbu Karang Di Pulau Mansinam Menggunakan Aplikasi Metode Underwater Photo Transect (UPT)
}

\author{
Yehiel H. Dasmasela ${ }^{1,3}$, Thomas F. Pattiasina ${ }^{2}$, Syafril ${ }^{1}$, Ricardo F. Tapilatu ${ }^{1,3}$ \\ ${ }^{1}$ Laboratorium dan Jurusan Ilmu Kelautan, Fakultas Perikanan dan Ilmu Kelautan - Universitas Papua \\ ${ }^{2}$ Laboratorium Manajemen Sumberdaya Perairan, Fakultas Perikanan dan Ilmu Kelautan - Universitas \\ Papua \\ ${ }^{3}$ Pusat Penelitian Sumberdaya Perairan Pasifik - Universitas Papua (UNIPA) - Manokwari \\ *凶 rf.tapilatu@unipa.ac.id
}

\begin{abstract}
Abstrak
Sejak tahun 2016, diperkenalkan metode monitor menggunakan Underwater Photo Transect (UPT) untuk menghasilkan hasil monitoring yang bersifat jangka panjang pada stasiun pengamatan yang tetap. Tujuan penelitian ini yaitu untuk menganalisis kondisi terumbu karang di Pulau Mansinam berdasarkan penerapan metode UPT, dan manfaat yang ingin dicapai dalam pemantauan kesehatan terumbu karang adalah tersedianya basis data dan informasi tentang kondisi ekosistem terumbu karang di Pulau Mansinam. Hasil analisis menunjukkan bahwa kondisi persen tutupan karang berdasarkan bentuk pertumbuhan berkisar 32-56\%, sehingga dikategorikan sedang. Hal ini menunjukkan bahwa Pulau Mansinam memiliki terumbu karang yang cukup baik tetapi mengalami tekanan aktifitas manusia yang merusak maupun karena adanya tekanan dari faktor alam. Nilai rata-rata tutupan karang di perairan pulau mansinam menunjukkan tingginya kerusakan karang, hal ini ditunjukkan dengan nilai patahan karang yaitu $25.62 \%$ dan karang hidup umumnya memiliki nilai yang rendah, berkisar antara $3-19 \%$.
\end{abstract}

Kata kunci: Pulau Mansinam, Underwater Photo Transect (UPT), Kondisi terumbu karang, pemantauan, persen tutupan

\section{PENDAHULUAN}

Sebagai salah satu ekosistem utama pesisir dan laut, terumbu karang dengan beragam biota asosiatif dan keindahan yang mempesona, memiliki nilai ekologis dan ekonomis yang tinggi. Selain berperan sebagai pelindung pantai dari hempasan ombak dan arus kuat, terumbu karang juga sebagai tempat mencari makanan, tempat asuhan dan tumbuh besar, serta tempat pemijahan bagi berbagai biota laut. Nilai ekonomis terumbu karang yang menonjol adalah sebagai tempat penangkapan berbagai jenis biota laut dan berbagai jenis ikan hias, bahan konstruksi dan perhiasan, bahan baku farmasi, dan sebagai obyek wisata bahari yang sangat menarik. Wilayah ini juga sebagai tempat atau rumah bagi sebagian biota laut karena dapat dijadikan sebagai daerah pemijahan (spawning ground), daerah pengasuhan (nursery ground), daerah mencari makan (feeding ground) dan daerah pembesaran (rearing). Selain itu, hal yang sedang trend dibicarakan saat ini yaitu koral dapat dijadikan sebagai sumber senyawa bioaktif farmakologi bahari. Bila sumber senyawa bioaktif pada tanaman biasanya berasal dari tanaman darat tingkat tinggi, akan tetapi sebaliknya untuk biota dilaut diketahui sumber senyawa bioaktif ada pada organisme tingkat rendah atau invertebrata dan karang. Dengan melihat nilai ekologis dan ekonomis penting tersebut, ekosistem terumbu 
karang sebagai ekosistem produktif di wilayah pesisir dan laut khususnya di Pulau Mansinam sudah selayaknya untuk dipertahankan keberadaan dan kualitasnya dengan cara pemantauan serta proses rehabilitasi (Burke et al., 2011).

Kondisi terumbu karang di Pulau Mansinam menurut Pasanea (2013) yaitu 70\% mengalami kerusakan karena aktifitas masyarakat dengan menggunakan alat tangkap yang tidak ramah lingkungan seperti bom, dan aktifitas-aktifitas yang merubah kualitas perairan. Dengan demikian sumberdaya yang menjadi penentu utama perekonomian masyarakat Pulau Mansinam tidak dilirik lagi kepada arah pemamfaatan yang berkelanjutan. Tidak hanya itu, konsekwensi tersebut tidak membuat masyarakat menyadari pentingnya menjaga sumber daya terumbu karang yang ada di wilayah Pulau Mansinam. Perkembangan metode yang dipakai untuk menilai kondisi terumbu karang di dunia dalam beberapa dekade belakangan mulai era tahun 1970-2000 terus berkembang. Beragam metode yang digunakan tersebut tidak terlepas dari adanya kelemahan baik dari segi teknis pelaksanaan lapangan, kemampuan sumberdaya manusia, maupun besarnya anggaran biaya yang diperlukan dalam penerapan masing-masing metode. Menurut (Giyanto, 2010) penggunaan metode manta tow (English et al., 1994; Sukmara et al., 2001) dapat menjangkau daerah penelitian yang lebih luas dengan waktu yang lebih singkat, tetapi akan sulit dan berbahaya jika dilakukan pada daerah yang penuh dengan karang keras yang berbentuk masif dengan ukuran besar. Penggunaan metode Line Intercept Transect (LIT) (Mundy, 1990; English et al., 1994; Hill and Wilkinson, 2004) diperlukan waktu yang lebih lama dibandingkan dengan metode manta tow, serta dibutuhkan kemampuan seseorang untuk menyelam dan kemampuan untuk mengidentifikasi karang sampai tingkat jenis. Pengambilan data dengan menggunakan metode Reef Resource Inventory (RRI) (Long et al., 2004) kelemahannya adalah data yang terambil tidak selengkap data yang diambil dengan menggunakan metode LIT (Adji et al., 2016).

Tujuan penelitian ini yaitu untuk menganalisis kondisi terumbu karang di Pulau Mansinam berdasarkan penerapan metode Underwater Photo Transect (UPT), sedangkan manfaat yang ingin dicapai dalam pemantauan kesehatan terumbu karang adalah tersedianya basis data UPT dan informasi tentang kondisi ekosistem terumbu karang di Pulau Mansinam.

\section{METODE PENELITIAN}

Penelitian ini dilaksanakan di Pulau Mansinam, Manokwari (Gambar 1) pada bulan Maret-April 2016. Pulau Mansinam teletak pada daerah perairan Teluk Doreri, secara geografis terletak di Kabupaten Manokwari Provinsi Papua Barat yang memiliki luas wilayah 12.500 ha, dengan posisi geografis $0^{\circ} 54^{\prime} 24.39^{\prime}$ LS dan $134^{\circ} 04^{\prime} 58.91^{\prime \prime}$ BT. Perairan ini memiliki batasan wilayah yaitu: sebelah Utara berbatasan dengan Samudera Pasifik, Selatan dengan Kabupaten Teluk Wondama, Barat dengan Kabupaten Sorong, Timur berbatasan dengan Kabupaten Biak Numfor. Jarak dari Pulau Mansinam ke Kota Manokwari $10 \mathrm{~km}$ yang ditempuh dengan menggunakan perahu (long boat). Di pulau ini hanya terdapat sebuah Sekolah Dasar. Oleh karena jarak, minimnya biaya transportasi dan terbatasnya gedung sekolah mengakibatkan banyak anak-anak yang putus sekolah dan memanfaatkan potensi perairan mereka dengan cara yang tidak ramah lingkungan untuk memenuhi kebutuhan hidup. 
Doi http://doi.org/md.v11i2.458

\section{Pengambilan Data Karang dengan Metode Underwater Photo Transect (UPT).}

Menurut Coremap (2006), pengambilan data di lapangan dilakukan dengan penyelaman menggunakan peralatan Self-Contained Underwater Breathing Apparatus (SCUBA) atau Perangkat Bernapas Bawah Air. Pengambilan data dengan metode UPT berdasarkan Panduan Monitoring Kesehatan Terumbu Karang Coremap-CTI LIPI 2014 (Giyanto dkk, 2014), dilakukan dengan pemotretan bawah air menggunakan kamera digital bawah air atau kamera digital biasa yang diberi pelindung (housing) sehingga tahan terhadap rembesan air laut. Kamera yang di anjurkan untuk digunakan yaitu kamera CANON G15 atau seri yang lebih tinggi.

Pengukuran parameter penunjang meliputi: suhu, salinitas, $\mathrm{pH}, \mathrm{DO}$, kecepatan arus dan kecerahan pada 7 stasiun pengamatan.

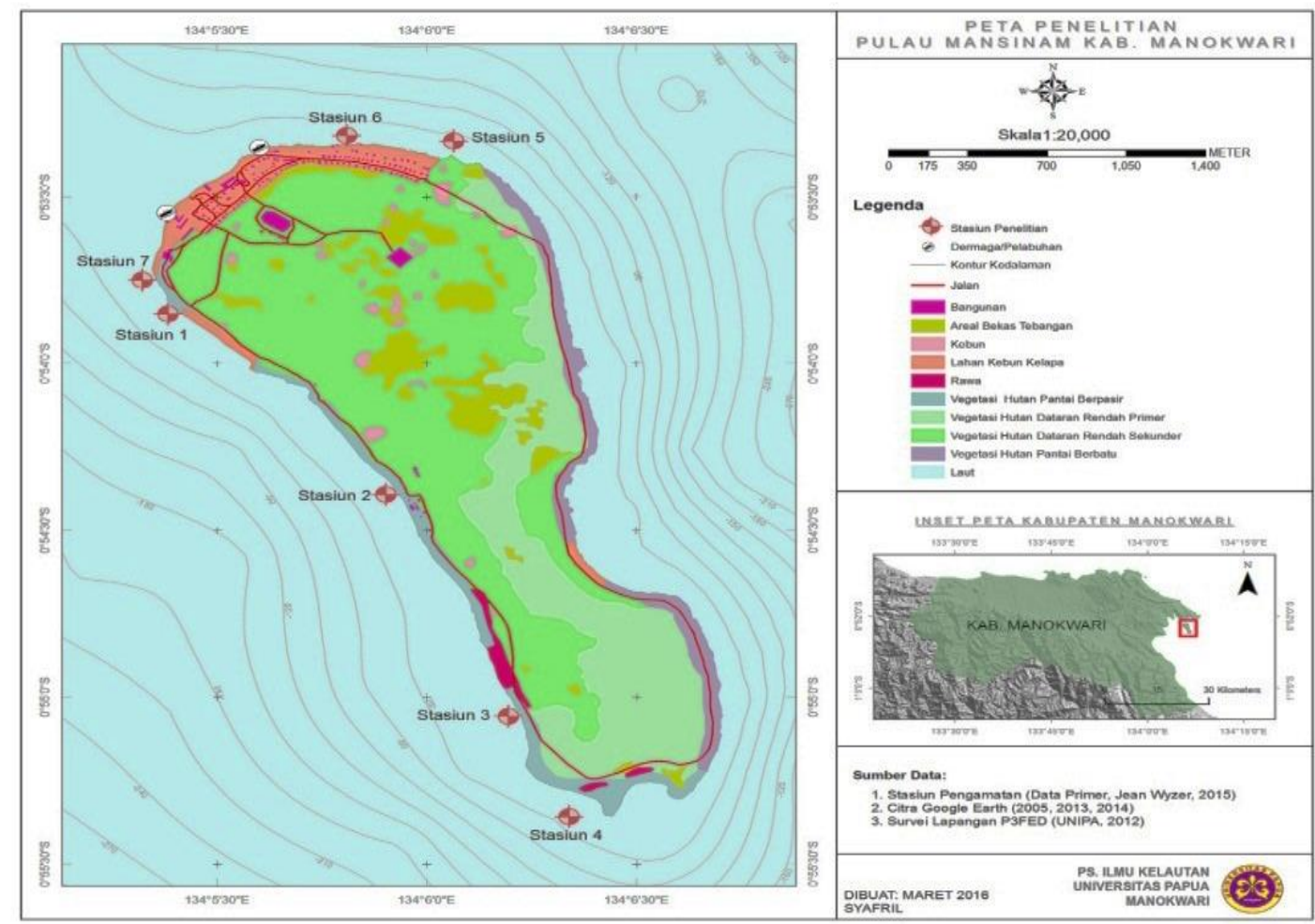

Gambar 1. Peta Lokasi Penelitian di Pulau Mansinam

\section{HASIL DAN PEMBAHASAN}

\section{Faktor Fisik-Kimia Perairan.}

Hasil pengukuran faktor fisik-kimia perairan tersaji pada Tabel 1.

Tabel 1. Faktor Fisik-Kimia Perairan Pulau Mansinam

\begin{tabular}{|c|c|c|c|c|c|c|c|c|c|c|}
\hline \multirow[b]{2}{*}{ No } & \multirow{2}{*}{$\begin{array}{c}\text { Kondisi } \\
\text { Fisik Kimia }\end{array}$} & \multicolumn{7}{|c|}{ Stasiun } & \multirow{2}{*}{$\begin{array}{l}\text { Mean } \pm \\
\text { SD }\end{array}$} & \multirow{2}{*}{$\begin{array}{l}\text { Permen LH } \\
\text { No } 51 \mathrm{Thn} \\
2004\end{array}$} \\
\hline & & I & II & III & IV & V & VI & VII & & \\
\hline 1 & Suhu & 29,5 & 29,7 & 30,5 & 30 & 30 & 29,6 & 29 & & $28-30$ \\
\hline 2 & & & 3 & & & 3 & & & & $32-36$ \\
\hline 3 & Kec. & 0,2 & 0,1 & 0,2 & 0 & 0, & 0, & 0, & & $0,1-0,5$ \\
\hline 4 & Kedal & 5 & 5 & 4 & 5 & 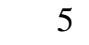 & & 5 & $4,86 \pm$ & $3-40$ \\
\hline 5 & Kecerahan & 100 & 100 & 100 & 10 & 0 & 100 & & & $>5$ \\
\hline 6 & $\mathrm{p}$ & 6.8 & 6,9 & 6,87 & 6,8 & 6, & 6, & 6 & $86 \pm 0,05$ & $6,5-8,5$ \\
\hline 7 & DO & 7,13 & 7,21 &, 24 &, 07 & 7,06 & 7,46 & 7,31 & $\pm 0,71$ & \\
\hline
\end{tabular}

Sumber: Keputusan Menteri Negara Lingkungan Hidup (2004) 
Pengukuran parameter fisika dan kimia dalam penelitian ini memiliki tujuan untuk mengetahui kesesuaian antara parameter fisika dan kimia air dengan kebutuhan karang. Hasil pengukuran kondisi fisik-kimia perairan Pulau Mansinam berada pada kondisi baik. Hal ini sesuai dengan Peraturan Menteri Lingkungan Hidup No 51 tahun 2004. Pulau Mansinam yang hanya memiliki luas 410,97 ha dan berada di dalam Teluk Doreri sehingga memiliki kondisi fisik-kimia yang relatif sama pada setiap stasiun pengamatan.

\section{Persentase Tutupan Karang Berdasarkan Lifeform Karang pada Aplikasi CPCe Stasiun I.}

Hasil pengamatan memperlihatkan bahwa tutupan karang tertinggi di Stasiun 1 terdapat pada kategori karang Soft Coral (SC) sebesar 26,04\% $\pm 11,34$ dan nilai tutupan terendah terdapat pada kategori Coral Foliose (CF) sebesar 0,13\% $\pm 0,47$. Hasil analisis menunjukkan bahwa Acropora Submassive (ACS), Coral Heliopora (CHL), Coral Mushroom (CMR), Coral submassive (CS), Macroalgae (MA) dan Turf Algae (TA) tidak ditemukan pada lokasi pengamatan.

Kategori tutupan karang SC tertinggi pada stasiun 1 disebabkan karena lokasi pengamatan berada di perairan yang berhadapan langsung dengan daerah terbuka dengan hempasan ombak yang kuat dari Perairan Pasifik. Soft Coral tersebut ditemukan tumbuh di tempat yang lebih dalam. Hal ini merupakan seleksi alam bagi hewan ini untuk menjaga koloninya dari kerusakan (Van Ofwegen, 2002). Selain itu, pada perairan tertentu dengan tingkat kejernihan yang baik, diameter koloni dapat mencapai 3m (Manuputty and Van Ofwegen, 2007, Manuputty, 2010, McFadden et al., 2006).

\section{Statiun II.}

Data menunjukkan bahwa persentase tutupan karang tertinggi di stasiun II terdapat pada kategori karang Coral Breanching $(C B)$ dengan nilai utupan sebesar $42,32 \% \pm 16,47$, diikuti Rubble $(R)$ sebesar 38,55\% $\pm 12,47$. Sedangkan persentase tutupan terendah terdapat pada kategori karang Old Dead Coral (ODC) sebesar 0,13\% $\pm 0,47$. Pada stasiun II tidak terdapat Acropora Digitate (ACD), Coral Encrusting $(C E)$, Coral Foliose (CF), Coral Heliopora (CHL), Coral Juvenile (Corju), Coral Millipora (CME), Coral Mushroom (CMR), Coral Submassive (CS), Sponges (SP), Macro Algae (MA) dan True Algae (TA) yang hanya persentase tutupan 0\% dikarenakan tempat ini merupakan gugusan terumbu karang tepi (fringing reef).

Tipe terumbu karang di perairan sekitar Pulau Mansinam adalah terumbu karang tepi (fringing reef). Bentuk dasar koloni karang lengkap, yaitu karang masif (massive), bercabang (branching), mengerak (encrusting), dan lembaran (foliaceous). Jenis dan jumlah life form khususnya yang mempunyai bentuk koloni bercabang dan massif cukup tinggi sehingga sangat mendukung kehidupan organisme laut. Tingginya persentase $\mathrm{CB}$, didukung oleh kondisi perairan yang jernih dan jauh dari sedimentasi sehingga penetrasi cahaya matahari dapat menembus perairan sampai $100 \%$ pada kedalaman 3-10 m. Menurut Chappell (1980) dalam Supriharyono (2007), di perairan yang jernih atau sedimentasi yang rendah, akan lebih banyak ditemukan karang dalam bentuk bercabang dan tabulate. 


\section{Stasiun III}

Kategori karang yang terdapat di stasiun III hanya sebanyak 10 kategori, dimana Sand $(S)$ dengan persentase tutupan sebesar $40 \% \pm 13,7$, diikuti Rubble $(R)$ dengan persentase tutupan sebesar 24,93\% $\pm 8,65$. Persen tutupan terendah pada kategori Coral Foliose $(C F)$ sebesar 0,27\% $\pm 0,66$. Katagori karang seperti Acropora Breanching (ACB), Acropora Digitate (ACD), Acropora Submasive (ACS), Coral Heliopora (CHL), Coral Juvenile (Corju), Coral Millpora (CME), Coral Mushroom (CMR), Old Dead Coral (ODC), Soft Coral (SC), Sponges (SP), Macro Algae (MA) dan True Algae (TA) tidak terdapat di lokasi pengamatan. Dengan persen tutupan Coral Breaching sebesar $27,13 \%$ menunjukan bahwa stasiun ini merupakan terumbu karang tepi (fringing reef) yang berfungsi sebagai penghalang dari gempuran ombak.

\section{Stasiun IV}

Hasil analisis menunjukan persen tutupan karang yang paling dominan berada pada kategori karang Coral Branching (CB) dengan nilai persen tutupan sebesar 45,13\% $\pm 17,12$. Tingginya persentase tutupan karang hidup jenis coral branching dikarenakan kondisi perairan stasiun penelitian IV yang berada di P. Mansinam ini cukup jernih dan terbuka serta mempunyai arus yang cukup kuat. Menurut Supriharyono (2007) bahwa tekanan hidrodinamis seperti arus dan gelombang akan memberikan pengaruh terhadap bentuk pertumbuhan karang ke arah bentuk pertumbuhan mengerak (encrusting). Namun sangat disayangkan pada stasiun penelitian ini persentase tutupan rubble juga cukup besar, berkisar $41,2 \% \pm 16,04$, sedangkan persen tutupan terendah terdapat pada kategori karang Old Dead Coral (ODC) sebesar 0,13\% $\pm 0,47$ diikuti oleh dead coral algae sebesar $12,60 \%$. Stasiun IV merupakan salah satu daerah penangkapan ikan hias oleh nelayan dari luar P. Mansinam, bahkan kegiatan pemboman ikan marak dilakukan di wilayah perairan ini.

Angka kerusakan terumbu karang pada stasiun ini lebih tinggi dibandingkan dengan pada stasiun lain. Tingginya persentase kerusakan karang diduga akibat kegiatan pemboman, sedangkan tingginya ODC adalah dampak kegiatan penangkapan ikan hias dengan menggunakan racun sianida. Dijelaskan oleh Suharsono (1998) bahwa penyemprotan sianida pada karang massive berakibat karang mengalami stress dengan mengeluarkan lendir. Dua bulan setelah percobaan pada karang yang diberikan perlakuan dengan penyemprotan sianida akan menyebabkan karang mengalami kematian pada bulan ketiga. Hal ini juga diduga karena Stasiun IV berada di daerah dengan laut terbuka, pengaruh pasang dan surut, kondisi perairan yang landai, sering terjadi aktivitas manusia yang merusak seperti mencari biota laut pada saat surut dan gelombang laut yang menyebabkan terjadi patahan karang (Dasmasela, 2014).

\section{Stasiun V}

Terdapat 14 kategori karang yang terdapat di Stasiun V. Rubble/patahan karang $(R)$ mendominasi dengan persen tutupan sebesar $22,33 \% \pm 10,13$, kemudian di ikuti Sand/pasir sebesar 21,8\% $\pm 11,29$. Sedangkan nilai terendah di dapat oleh Sponges dan True Algae dengan nilai persen tutupan yang sama yaitu sebesar 0,007\% $\pm 0,24$.

Kerusakan terumbu karang pada lokasi penelitian disebabkan oleh aktivitas masyarakat yang bermukim di Pulau Mansiam yang dalam kegiatan menangkap ikan menggunakan alat tidak ramah lingkungan seperti bom dan racun ikan (putas) serta penambangan karang. Selain itu, karena lokasi penelitian yang berdekatan dengan pelabuhan sehingga sering perahu nelayan maupun perahu yang memuat penumpang 
yang berknjung ke Pulau Mansinam sebagi Situs Sejarah di Tanah Papua membuang jangkar mengakibakan terjadi patahan karang. Menurut Papu (2011) bahwa pertumbuhan karang dipengaruhi oleh faktor alam dan manusia. Faktor alam seperti ketersediaan nutrisi, predator, kondisi kimia-fisika laut, jika dalam keadaan sesuai maka dapat membuat kondisi terumbu karang lebih stabil. Faktor manusia, seperti pengeboman ikan, penggunaan jangkar di daerah terumbu karang yang merusak terumbu karang.

Indarjo et al., (2004) mengemukakan bahwa potensi sumberdaya terumbu karang di Indonesia semakin menurun dan terancam rusak. Kerusakan terumbu karang di Indonesia diindikasikan terutama sebagai akibat aktivitas manusia. Praktek penangkapan ikan yang tidak ramah lingkungan, seperti pemboman, pembiusan dan penggunaan racun oleh nelayan di sekitar terumbu karang, dan penambangan karang dan pasir juga turut andil terhadap kerusakan sumberdaya terumbu karang.

\section{Stasiun VI}

Terdapat kisaran angka yang bervariasi pada setiap variabel yang diamati di Station VI. Kategori nilai persen tutupan tertinggi terdapt pada patahan karang/Rubble $(R)$ sebesar 31,13\% $\pm 13,72$. Kisaran ini menunjukan bahwa terumbu karang di stasiun 6 cukup memprihatinkan. Nilai persen tutupan tertinggi yaitu pasir/Sand (S) dengan nilai $24,8 \% \pm 9,03$. Sedangkan persen tutupan karang yang paling sedikit adalah Acropora Branching ( $A C B)$ dan Coral Foliose $(C F)$ memiliki nilai persen tutupan yang sama yaitu $0,13 \%$ tetapi dengan rata-rata standar deviasi yang berbeda yaitu $\pm 0,47$ dan $\pm 0,33$. Sama halnya pada stasiun IV, $R$ mendominasi perairan di karenakan lokasi ini tepat berada pada sebelah depan pulau yang biasanya dijadikan sebagai daerah wisata yang menyebabkan karang di daerah ini sering di injak-injak menyebabkan karang tersebut patah.

Selain letaknya di sisi utara pulau yang merupakan lokasi wisata, Stasiun 6 juga merupakan lokasi dimana terkonsentrasi permukiman masyarakat lokal di Pulau Mansinam (Gambar 1. Peta Lokasi Penelitian). Berdasarkan pengamatan di lapangan, kegiatan penangkapan ikan dan pengumpulan bota laut yang dilakukan oleh masyarakat setempat di lokasi Stasiun VI sangat intens, terutama ketika air surut. Kegiatan-kegiatan yang terpantau diantaranya penangkapan ikan dengan jaring, pengumpulan biota laut seperti kerang, dan menyelam untuk memanah ikan. Dalam melakukan aktivitas tersebut, masyarakat setempat lebih sering berjalan, dan kalaupun berenang atau menyelam ada saatnya mereka beristirahat sambil berdiri sehingga peluang karang yang untuk terinjak sangat besar. Hal ini menyebabkan di lokasi ini presentasi tutupan patahan karang (rubble) lebih besar dibandingkan presentase tutupan kelas lainnya. Menurut Smith et al. (2016), terumbu yang berada di dekat populasi masyarakat lokal kurang bervariasi dan biasanya di dominasi oleh turf dan makroalga, bahkan patahan karang (rubble) dan karang mati. Dikemukakan pula bahwa habitat bentik yang dekat dengan populasi masyarakat bisa kehilangan layanan ekologi yang paling signifikan, yaitu kemampuan untuk membangun terumbu-terumbu karbonat oleh karena tekanan aktivitas masyarakat.

\section{Stasiun VII}

Persen tutupan yang mendominasi di stasiun VI yaitu pasir/Sand (S) dengan nilai persen tutupan sebesar $25,13 \% \pm 11,62$, diikuti patahan karang/Rubble (R) dengan nilai persen tutupan sebesar 21,2\% 7,46. Sedangkan Coral Mushroom dan Soft Coral 
memperoleh nilai persen tutupan karang yang sama yaitu $0,13 \%$ namun memiliki nilai standar deviasi yang berbeda yaitu $0,33 \%$ dan $0,47 \%$.

Stasiun VII terletak berhadapan dengan Pulau Lemon, yaitu Pulau kecil yang letaknya di sebelah barat laut dari Pulau Mansinam. Jarak antara Pulau Mansinam dan Pulau Lemon cukup dekat, sehingga berbentuk seperti celah yang sempit diantara kedua pulau. Manaf (2008) yang melakukan penelitian pola arus di Teluk Doreri mengemukakan bahwa umumnya arus kuat terjadi pada bagian sempit antara Pulau Lemon dan Pulau Mansinam. Pola arus mengalami pembelokan arah ketika melewati Pulau Lemon yang dapat mencapai $0,3 \mathrm{~m} / \mathrm{s}$, dengan kecepatan rata-rata $0,22 \mathrm{~m} / \mathrm{s}$. Pergerakan arus yang kuat ini diduga menjadi penyebab penumpukan pasir dan patahan karang di Stasiun VII. Menurut Patsch and Griggs (2006) arus sejajar pantai (longshore current) dan turbulensi gelombang pecah, yang berfungsi untuk menangguhkan pasir adalah faktor penting yang terlibat dalam menggerakkan pasir di sepanjang garis pantai. Semakin kuat arus, semakin besar volume pasir yang dipindahkan. Persentase patahan karang yang cukup besar di lokasi Stasiun 7 juga diduga disebabkan oleh arus yang kuat di lokasi ini. Aksi gelombang yang kuat dapat mematikan yang dapat menghasilkan gaya seret yang besar, yang dapat mematahkan karang atau memangkas struktur karang. Pada kondisi demikian, karang bercabang akan lebih rentan patah atau rusak dibandingkan dengan karang masif (Monismith, 2007, Rogers, 2013).

\section{Persentase Tutupan Karang di Semua Stasiun Pengamatan}

Pengambilan data dilakukan di 7 lokasi mewakili secara keseluruhan perairan Pulau Mansinam (Gambar 1). Persen tutupan karang berdasarkan lifeform pada 7 lokasi pengambilan data (Gambar 2).

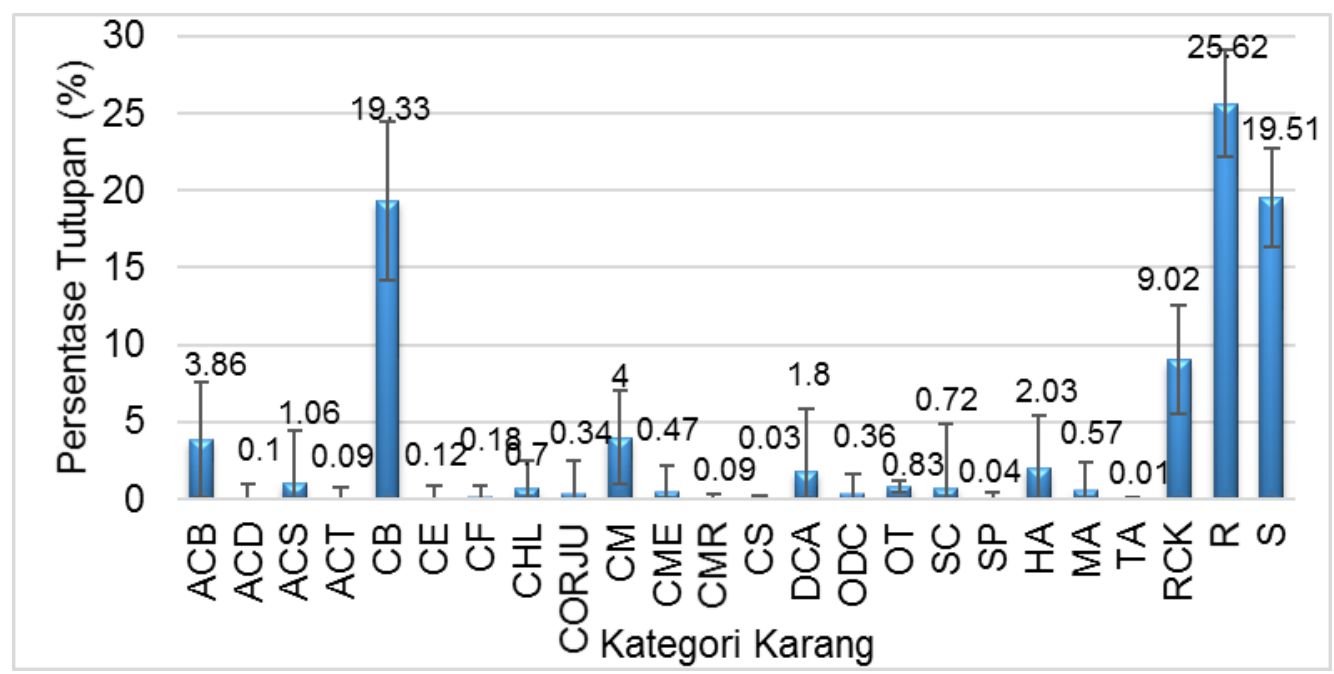

Gambar 2. Persentase tutupan lifeform karang di Pulau Mansinam

Gambar 2 memperlihatkan kisaran angka yang bervariasi pada setiap kategori karang yang diamati. Walaupun demikian, hasil analisis di atas memperlihatkan bahwa nilai tutupan tertinggi terdapat pada patahan karang (rubble) yaitu sebesar $25,62 \% \pm 3,47$. Nilai presentase tutupan ini menunjukkan bahwa kondisi terumbu karang di Pulau Mansinam cukup memprihatinkan dan perlu mendapat perhatian secara serius dari berbagai pihak. Setelah patahan karang, kategori dengan presentase tutupan tertinggi berikutnya adalah sand/pasir dengan presentase tutupan $19,51 \% \pm 3,17$. Pada beberapa lokasi pengamatan, pasir ditemukan cukup mendominasi daerah sekitar 
hamparan terumbu karang. Hasil yang diperoleh ini sejalan dengan penelitian Pasanea (2013), dimana komponen abiotik yang terdiri dari rubble/patahan karang dan sand/pasir mendominasi dasar perairan Pulau Mansinam. Patahan karang ini diduga diakibatkan oleh aktifitas penangkapan ikan menggunakan bom. Praktek penangkapan ikan dengan menggunakan bom mengakibatkan patahnya karang dan pertumbuhan karang yang buruk. Meskipun upaya penyadaran telah dilakukan oleh pemerintah dan perguruan tinggi, namun praktek-praktek penangkapan ikan yang merusak masih tetap berlangsung.

Menurut Chabanet et al. (2012) tidak mudah untuk memperkirakan durasi dari pengaruh yang berasosiasi dengan aktivitas penangkapan merusak, karena pada kenyataannya aktivitas-aktivitas tersebut memiliki dampak yang tidak teratur atau bersifat kronik. Dikemukakan pula bahwa aktivitas penangkapan ikan yang merusak dengan bom maupun aktivitas lain yang memberi peluang terinjaknya karang dapat menyebabkan patahnya karang dan akumulasi patahan karang pada lokasi-lokasi yang sebelumnya merupakan habitat karang hidup. Meskipun tingkat kerusakan habitat oleh kegiatan-kegiatan tersebut biasanya mencakup tingkat skala kecil, misalnya 1-10 m unit spasial, namun jika tidak segera ditangani maka kerusakan dapat mencakup areal yang luas.

Nilai tutupan berikut yang ditemukan yaitu kategori karang bercabang (coral branching) dengan nilai tutupan 19,33\% $\pm 5,16$. Karang bercabang merupakan salah satu jenis karang dengan bentuk tubuh bercabang, memiliki cabang lebih panjang dari diameternya, banyak terdapat di sepanjang tepi terumbu dan bagian atas lereng, terutama yang terlindungi atau setengah terbuka, serta banyak memberikan tempat perlindungan bagi ikan dan invertebrata. Jenis karang ini umumnya ditemukan pada kedalaman $5-15 \mathrm{~m}$, serta lokasi yang cukup tenang dan pengaruh ombak yang sangat sedikit. Seperti layaknya rubble dan sand, coral branching mendominasi dasar perairan Pulau Mansinam.

Penelitian Pasanea (2013) terhadap life coral dimana salah satunya terdapat coral branching yang tumbuh subur di Perairan Pulau Mansinam, hal ini disebabkan karena kondisi kualitas perairan seperti suhu pada daerah ini cocok untuk pertumbuhan karang yaitu dengan nilai $30,6^{\circ} \mathrm{C}$. Supriharyono (2007) mengemukakan bahwa kisaran nilai salinitas perairannya juga memperlihatkan kondisi yang baik untuk pertumbuhan karang, berkisar antara 30-32\%o. Nybakken (2007) menambahkan bahwa kisaran ini sangat cocok untuk pertumbuhan karang. Kondisi perairan sekitar Pulau Mansinam yang cukup tenang karena terlindung di dalam Teluk Doreri merupakan habitat yang baik untuk pertumbuhan jenis-jenis karang bercabang, terutama dari Genus Porites, khususnya jenis Porites cylindrica yang memang ditemukan cukup melimpah di lokasi sebelah barat Pulau Mansinam. Menurut Fitt et al. (2009), Porites cylindrica adalah jenis karang bercabang yang habitatnya di daerah lagun yang relatif tenang dan terlindung dari angin. Jenis tersebut tumbuh dengan baik di zona back reef yang hangat, serta mempunyai kemampuan tahan terhadap perubahan suhu. Menurut Brien et al. (2015), genus Porites umumnya toleran terhadap berbagai tekanan lingkungan. Berdasarkan hasil uji mereka, karang bercabang jenis Porites cylindrica tahan terhadap peningkatan level $\mathrm{CO}_{2}$ di air laut.

Batu/rock mendapatkan nilai persentase tutupan sebesar 9,02\% 33,53 , batu/rock merupakan bongkahan karang mati yang dimanfaatkan organisme lain untuk menempel dan membentuk koloni baru. Selanjutnya coral massive (CM) memiliki nilai yang sedikit rendah dari batu/rock, yaitu dengan nilai tutupan $4.00 \% \pm 3,02$. Karang ini 
berbentuk padat (massive), dengan ukuran bervariasi serta beberapa bentuk seperti bongkahan.

Kategori Acropora branching (ACB) memiliki nilai tutupan sebasar 3,86\% $\pm 3,74$, terdapat kesamaan dari jenis karang ACB dan ACT karena kedua jenis ini sama-sama mempunyai bentuk pertumbuhan yang bercabang. Kategori ini didapatkan pada lokasi yang tidak terlalu berombak. Setelah ACB, hasil yang didapat selanjutnya yaitu halimeda dan acropora submassive dengan nilai tutupan berturut-turut sebesar $2,03 \% \pm 3,43$ dan $1,06 \% \pm 3,38$. Persen tutupan karang terendah berdasarkan kategori (Tabel 3).

Tabel 3. Persentase Tutupan Terendah Berdasarkan Kategori

\begin{tabular}{clc}
\hline Nomor & \multicolumn{1}{c}{ Jenis } & Tutupan $(\%)($ Mean \pm SD) \\
\hline 1 & Acropora Digitatae (ACD) & $0,1 \pm 0,89$ \\
2 & Acropora Tabulate (ACT) & $0,09 \pm 0,64$ \\
3 & Coral Encrusting (CE) & $0,12 \pm 0,80$ \\
4 & Coral Foliiose (CF) & $0,18 \pm 0,66$ \\
5 & Coral Heliopora (CHL) & $0,7 \pm 1,85$ \\
6 & Coral juvenil (CORJU) & $0,34 \pm 2,18$ \\
7 & Coral Millepora (CME) & $0,47 \pm 1,65$ \\
8 & Coral Musroom (CMR) & $0,09 \pm 0,26$ \\
9 & Coral Submasive (CS) & $0,3 \pm 0,18$ \\
10 & Old Dead Coral (ODC) & $0,36 \pm 1,33$ \\
11 & Other (OT) & $0,83 \pm 0,37$ \\
12 & Soft Coral (SC) & $0,72 \pm 4,15$ \\
13 & Sponges (SP) & $0,04 \pm 0,38$ \\
14 & Marcoalgae (MA) & $0,57 \pm 1,77$ \\
15 & True Algae (TA) & $0,01 \pm 0,09$ \\
\hline
\end{tabular}

Sumber : Data Hasil Penelitian (2016)

\section{Persentase Tutupan Karang di Pulau Mansinam}

Hasil pemantauan persentase tutupan karang di Pulau Mansinam dengan menggunakan metode UPT (Gambar 3).

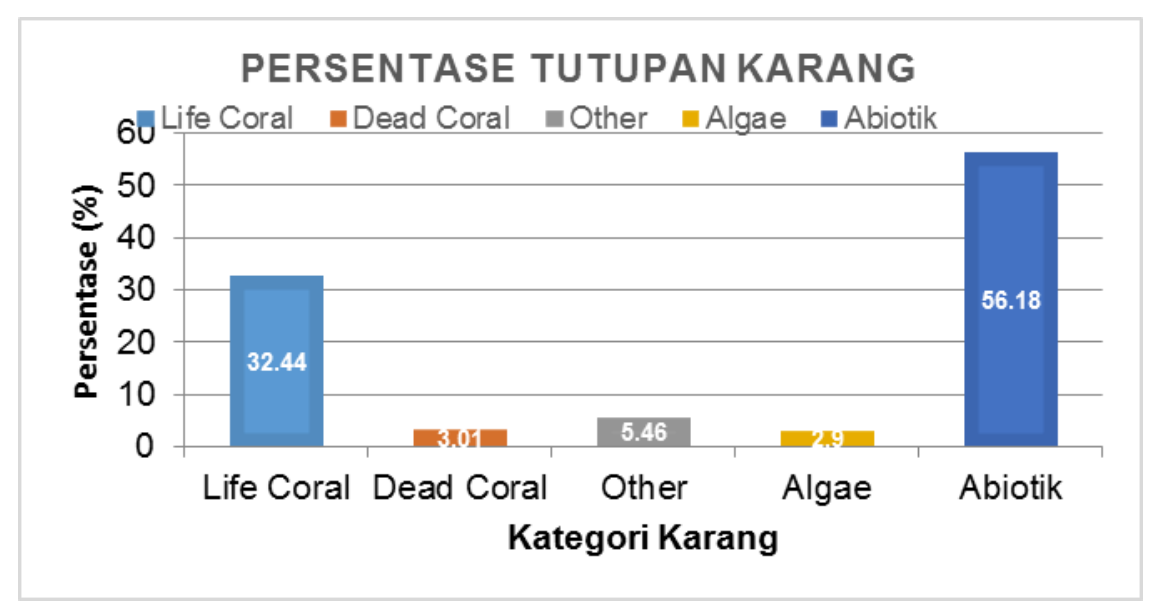

Gambar 10. Persentase Tutupan Karang di Perairan Pulau Mansinam

Berdasarkan data pada Gambar 10, dapat dilihat bahwa pesentase tutupan karang hidup (lifecoral) sebesar 32\%, karang mati (dead coral) sebesar 3\%, other sebesar 6\%, sedangkan algae dan abiotik berturut-turut sebesar 3\% dan 56\%. Hal ini menunjukkan bahwa persentase tertinggi tutupan karang adalah abiotik. Katagori Other disini adalah 
halimeda, macroalgae, soft coral, zoanthid, sponges, algae assemblage, true algae dan other (ascidians, anemon, akar bahar dan kima), sedangkan kategori abiotik adalah rubble (patahan karang), sand (pasir) dan rock (batu). Berdasarkan persentase tutupannya, maka kondisi terumbu karang di Pulau Mansinam termasuk dalam katagori sedang. Hal ini menunjukan bahwa Pulau Mansinam memiliki terumbu karang yang cukup baik. Hal ini diperkuat dengan penelitian Pasanea (2013) yang menyatakan bahwa dari keseluruhan lokasi yang diamatinya, keadaan terumbu karangnya berada dalam kondisi yang sedang atau sudah mengalami kerusakan dikarenakan aktivitas masyarakat dalam memanfaatkan sumberdaya laut yang tidak ramah lingkungan. Sedangkan menurut Krey (2014), kondisi terumbu karang di Pulau Mansinam dalam katagori sedang dengan persentase kategori abiotik mendominasi perairan tersebut.

Pasanea (2013) membenarkan hal ini karena sesuai dengan kondisi di lapangan yang menunjukkan banyaknya kematian karang akibat penggunaan bahan peledak (banyak ditemukan pecahan karang atau rubble), selain penggunaan bom, aktivitas lain yang merusak terumbu karang berupa penggunaan bius (sianida) oleh masyarakat setempat. Analisis tutupan karang yang dilakukan oleh Krey (2014) menunjukan bahwa kondisi terumbu karang dalam keadaan sedang, dengan rata-rata tutupan karang 53.24\%. Daerah ini didominasi oleh pertumbuhan karang keras yaitu Coral brancing, Acropora Submassive dan Coral Massive, sebanyak 73,80\%, dimana tempat ini merupakan gugusan terumbu karang tepi (fringing reef) yang berfungsi sebagai pelindung terhadap arus dan gelombang yang kuat terhadap abrasi pantai. Berdasarkan pengamatan terhadap proyek pembangunan Balai Benih Ikan Kerapu baik tahap prakonstruksi dan tahap konstruksi di Pulau Mansinam sejak tahun 2010 (tahap I), telah terjadi kerusakan terumbu karang, 2012 (tahap II) tidak memberikan dampak terhadap kerusakan terumbu karang, dan 2013 (tahap III) juga tidak menimbulkan dampak (Krey, 2014).

\section{KESIMPULAN}

Berdasarkan hasil pemantauan kondisi terumbu karang di Pulau Mansinam dapat disimpulkan bahwa: Persen tutupan karang berdasarkan bentuk pertumbuhan berkisar $32-56 \%$ sehingga dikategorikan kategori sedang. Hal ini menunjukan bahwa Pulau Mansinam memiliki terumbu karang yang cukup baik tetapi mengalami tekanan aktifitas manusia yang merusak maupun karena adanya tekanan dari faktor alam. Nilai rata-rata tutupan karang di perairan pulau mansinam menunjukkan tingginya kerusakan karang. Hal ini ditunjukkan dengan nilai patahan karang yaitu 25,62\% dan karang hidup umumnya memiliki nilai yang rendah yaitu berkisar antara 3-19\%.

\section{DAFTAR PUSTAKA}

Bonnke P. Sagai, Kakaskasen A. Roeroe, Indri S. Menembu. 2017. Kondisi Terumbu Karang di Pulau Salawati Kabupaten Raja Ampat Papua Barat. Jurnal Pesisir dan Laut Tropis (1) 2: 47-52

Brien, H., Watson, S. \& Hoogenboom, M. 2015. Presence of competitors influences photosynthesis, but not growth, of the hard coral Porites cylindrica at elevated seawater CO2. ICES Journal of Marine Science, 73, 659-669.

Burke L., Reytar K., Spalding M., Perry A., 2011 Reefs at Risk Revisited. World Resources Institute, Washington DC, 114 p.

Chabanet, P., Loiseau, N., Join, J.-L. \& Ponton, D. 2012. VideoSolo, an autonomous video system for high-frequency monitoring of aquatic biota, applied to coral reef 
Doi http://doi.org/md.v11i2.458

fishes in the Glorioso Islands (SWIO). Journal of Experimental Marine Biology and Ecology, 430, 10-16.

COREMAP; 2006. Manual Monitoring Kesehatan Karang (Reef Health Monitoring). In: MONITORING, T. R. (ed.). Jakarta. halaman

Dasmasela, Y. H. Pengaruh Kedalaman Perairan Terhadap Laju Pertumbuhan Karang Jenis Montipora digitata Hasil Transplantasi di Pulau Lemon. Seminar Nasional Hasil-Hasil Penelitian, 2014 Bali. 615-616.

English, S; C. Wilkinson \& V. Baker. 1997. Survey Manual for Tropical Marine Resources. Ed ke-2. Townsville: AIMS. 390p.

English, S., Wilkinson, C., and Bakert, V. 1994. Survey Manual for Tropical Ma-rine Resources. Australian Institute of Marine Science. 368p.

Fitt, W., Gates, R., Hoegh-Guldberg, O., Bythell, J., Jatkar, A., Grottoli, A., Gomez, M., Fisher, P., Lajuenesse, T. \& Pantos, O. 2009. Response of two species of IndoPacific corals, Porites cylindrica and Stylophora pistillata, to short-term thermal stress: the host does matter in determining the tolerance of corals to bleaching. Journal of experimental marine biology and ecology, 373, 102-110.

Giyanto, B., Iskandar, D., Soedharma \& Suharsono 2010. Efisiensi dan akurasi pada proses analisis foto bawah air untuk menilai kondisi terumbu karang. Oseanologi dan Limnologi Indonesia 36, 111-130. sebaiknya jurnal ini dibahas di pendahuluan

Giyanto. 2012a. Kajian tentang Panjang Transek dan Jarak Antara Pemotretan pada Penggunaan Metode Transek Foto Bawah Air. Oseanologi dan Limnologi di Indonesia 38 (1): 1-18)

Giyanto. 2012b. Penilaian Kondisi Terumbu Karang dengan Metode Foto Transek Bawah Air. Oseanologi dan Limnologi di Indonesia 38 (3): 377-390.

Giyanto. 2013. Metode Transek Foto Bawah Air untuk Penilaian Kondisi Terumbu Karang. Oseana, 38 (1): 47-61

Giyanto, Manuputty, A. E. W., Abrar, M., Siringoringo, R. M., Suharti, S. R., Wibowo, K., Edrus, I. N., Arbi, U. Y., Cappenberg, H. A. W., Sihaloho, H. F., Tuti, Y., dan Zulfianita, D. 2014. Panduan Monitoring Kesehatan Terumbu Karang: Terumbu Karang, Ikan Karang, Megabenthos dan Penulisan Laporan. Coremap CTI LIPI, Jakarta.

Hill, J. and Wilkinson. 2004. Methods for ecological monitoring of coral reefs. Versi ke-1, a resources for managers. Townsvile. AIMS. 117p.

Indarjo, A., Widyatmoko, W. \& Munasik 2004. Kondisi Terumbu Karang di Perairan Pulau Panjang Jepara. Ilmu Kelautan: Indonesian Journal of Marine Sciences, 9, 217-224.

Kohler, K. E., dan Gill, S. M. 2006. Coral Point Count with Excel extensions (CPCe): A Visual Basic program for the determination of coral and substrate coverage using random point count methodology. Computer and Geosciences 32 (9): 1259-1269.

Krey, M. 2014. Keterkaitan Terumbu Karang dengan Ikan Chaetodontidea dan implikasi untuk Pengelolaan Perairan Teluk Doreri Kabupaten Manokwari Papua Barat. Universitas Papua.???

Long, B.G.; G. Andrew; Y.G. Wang \& Subarsono. 2004. Sampling Accuracy of Reef Resource Inventory Technique. Coral Reefs 23:378-385.

Menteri Lingkungan Hidup. 2001. Keputusan Menteri Lingkungan Hidup Nomor 4 Tahun 2001 Tentang Standar Baku Mutu Kerusakan Lingkungan Hidup. Jakarta. 
Manaf, S. 2008. Simulasi Model Numerik Hidrodinamika Teluk Doreri Kabupaten Manokwari Dengan Metode Beda Hingga Eksplisit. Perikanan dan Kelautan, 4, 14.hanya 1 halaman?

Manuputty, A. 2010. Sebaran karanglunak marga Sinularia May, 1898 (Octocorallia, Alcyonacea) di Pulau-pulau Derawan, Kalimantan Timur. Oseanologi dan Limnologi di Indonesia, 36, 211-225.

Manuputty, A. \& Van Ofwegen, L. 2007. The genus Sinularia (Octocorallia: Alcyonacea) from Ambon and Seram (Moluccas, Indonesia). Zoologische Mededelingen, 81, 187.hanya 1 halaman?

McFadden, C., Alderslade, P., Van Ofwegen, L., Johnsen, H. \& Rusmevichientong, A. 2006. Phylogenetic relationships within the tropical soft coral genera Sarcophyton and Lobophytum (Anthozoa, Octocorallia). Invertebrate Biology, 125, 288-305.

Monismith, S. 2007. Hydrodynamics of coral reefs. Annu. Rev. Fluid Mech., 39, 37-55.

Mundy, C.N. 1990. Field and laboratory investigations of line intercept transect technique for monitoring the effects of the crown-of-thorns starfish, Acant-haster planci. Townsville. AIMS. 42p.

Nybakken, J. 2007. Biologi Laut: Suatu Pendekatan Ekologis.halaman

Papu, A. 2011. Kondisi Tutupan Karang Pulau Kapoposang, Kabupaten Pangkajene Kepulauan, Provinsi Sulawesi Selatan. Jurnal Ilmiah Sains, 11, 6-12.

Pasanea, E. 2013. Kondisi Terumbu Karang dan Penyusunan Konsep Strategis Pengawasan Ekosistem Terumbu Karang di Pulau Mansinam Kabupaten Manokwari. Hasanuddin.

Patsch, K. \& Griggs, G. 2006. Littoral cells, sand budgets, and beaches: understanding California's shoreline, Institute of Marine Sciences.vol, issue, halaman

Phinn, S.R., C.M. Roelfsema, and P.J. Mumby. 2012. Multi scale, object-based image analysis for mapping geomorphic and ecological zones on coral reefs. International Journal of Remote Sensing, 33(12):3768-3797.

Rogers, C. 2013. Coral reef resilience through biodiversity. ISRN Oceanography, 2013.

Smith, J., Brainard, R., Carter, A., Grillo, S., Edwards, C., Harris, J., Lewis, L., Obura, D., Rohwer, F. \& Sala, E. 2016. Re-evaluating the health of coral reef communities: baselines and evidence for human impacts across the central Pacific. Proc. R. Soc. B, 283, 20151985.

Suharsono 1998. Condition of Coral Reef Resources in Indonesia. Indonesian Journal of Coastal and Marine Resources Management. PKSPL-IPB, 1, 44-52.

Sukmara, A., A.J. Siahainenia, C. Rotinsulu . 2001. Panduan pemetaan terumbu karang berbasis-masyarakat dengan metode manta tow. Jakarta: Proyek Pesisir-CRMP Indonesia. 48p.

Supriharyono, M. 2007. Pengelolaan ekosistem terumbu karang, Djambatan. jumlah halaman

Van Ofwegen, L. Status of knowledge of the Indo-Pacific soft coral genus Sinularia May, 1898 (Anthozoa: Octocorallia). Proc 9th Intl Coral Reef Symp, 2002.nama kota 